\title{
EDITORIAL
}

\section{Maurice Campbell: first editor of Heart}

\author{
M E Silverman
}

Heart 2003;89:1379-1381

Maurice Campbell was the first editor of the British Heart Journal, now Heart, and was called the journal's progenitor and formative influence, an untiring editor who virtually produced each issue single handedly. Campbell was also valued for his scholarly opinions, organisational and editorial skills, and for his careful statistical work which was advanced for its time and of great importance in the early understanding and treatment of congenital heart disease and arrhythmias. In addition, his collaboration with Russell Brock was instrumental in developing surgery for rheumatic and congenital heart disease at Guy's Hospital.

*From the Department of Medicine, Emory University of Medicine, and the Fuqua Heart Centre of Piedmont Hospital, Atlanta, Georgia, USA

Correspondence to: *Professor Mark E Silverman, 1968 Peachtree Road, NW, Atlanta, Georgia 30́309, USA; marksil@comcast.net

\begin{abstract}
"I should like to give one message, ...the importance of following up groups of patients: we sometimes think of this as an uninteresting form of research, but now that we have to take decisions about when to advise operation for these patients we realise the urgent need of accurate knowledge of the natural history and prognosis, and this is often very incomplete even for common conditions." Maurice Campbell'
\end{abstract}

In 1972 Maurice Campbell (fig 1), the first editor of the British Heart Journal, now Heart, was honoured by the British Heart Journal. The editorial by $\mathrm{K}$ Shirley Smith called Campbell the journal's progenitor and formative influence, issue single handedly. The editorial ended by saying, "Physician, thinker, naturalist, and indefatigable worker Maurice Campbell adorns the splendid traditions of British medicine."'2 Now, over 30 years later, most of Campbell's contemporaries are gone and only a few still remember his many accomplishments that deserved such a tribute.

\section{CAREER}

John Maurice Hardman Campbell (1891-1973) was known especially for his important studies on the natural history of congenital heart disease and his productive collaboration with Russell Brock to pioneer surgical correction of heart disease at Guy's Hospital after the second world war. Known as Maurice Campbell, he was schooled at Winchester and then New College, Oxford where he gained a first class degree in physiology. He entered Guy's Hospital Medical an untiring editor who virtually produced each
School in London in 1914 and graduated in 1916. During the first world war, he served in the Royal Army Medical Corps in Mesopotamia and North Persia, receiving the Order of the British Empire for his services with a field ambulance unit. In 1920, Campbell returned to Guy's Hospital, working first as a medical registrar then spending three years in the department of physiology where he became interested in the effects of oxygen. After a Beit memorial research fellowship from 1923-1927, Campbell became an assistant physician at Guy's in 1926, a general physician in 1945, and a cardiologist in 1948, heading their newly founded cardiac department. In 1930, he was additionally appointed as a consultant to the National Heart Hospital. During the second world war, Campbell was superintendent of the emergency medical service at Orpington, Kent which was closely linked with Guy's Hospital receiving evacuees from the London air raids. His marriage to Mary Crimes, a nurse at Guy's Hospital, was a happy one, and they had five children, one becoming a nurse and another a zoologist. ${ }^{3-5}$

\section{PROFESSIONAL ACCOMPLISHMENTS}

Campbell was an early member of the Cardiac Club, the forerunner of the British Cardiac Society, of which he was appointed the first secretary from 1936-1946, and he followed John Parkinson as their second president from 1956 to 1960. He was also their historian. ${ }^{6}$ In 1938, he became the first editor of the British Heart Journal (along with Evan Bedford) which he continued to edit for 20 years until 1958. ${ }^{7}$ He was known to review manuscripts sitting amidst the bustle of the underground subway and to foster high standards by working closely with authors to achieve clarity of expression while giving much of his time to guide potential contributors. As president of the British Cardiac Society, he suggested and helped found the British Heart Foundation to raise funds for cardiac research. He was also Governor at both Guy's Hospital and the National Heart Hospital. Campbell was the St Cyres lecturer at the National Heart Hospital in 1934, speaking on the "Aetiology of the cardiac arrhythmias", 8 and he delivered the Lumleian Lecture on "The paroxysmal tachycardias" to the Royal College of Physicians in 1946. ${ }^{9}$ For his many contributions to British cardiology, he received the Moxon Medal from the Royal College of Physicians in 1966.

\section{INTERESTS IN ORNITHOLOGY AND SHERLOCK HOLMES}

His interests also included a great knowledge of ornithology and Sherlock Holmes. In 1955, he published an article cataloguing the birds he had 


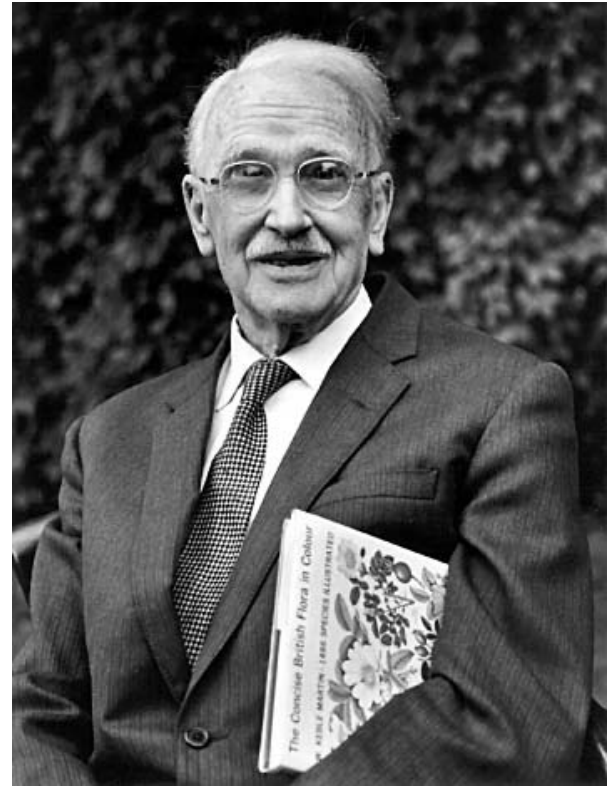

Figure 1 Maurice Campbell holding a book on wild flowers. Photograph used by permission of the Royal College of Physicians.

identified during an Atlantic crossing. ${ }^{10}$ On one occasion, a student told Campbell that he heard a seagull murmur. Campbell responded, "Which seagull?". He was an active member of the Sherlock Holmes Society, writing articles and a book, Sherlock Holmes and Doctor Watson: a medical digression, in which he skilfully reviews the many medical, anatomical, chemical, and pharmacologic aspects of the novels and comments on their accuracy. Campbell also posed as Doctor Watson during a re-enactment of Moriarity's attempted murder of Holmes at the Reichenbach falls. He was thought well suited for the part because of his resemblance to the fictitious Watson. ${ }^{511}$

\section{PUBLICATIONS AND INTEREST IN CONGENITAL HEART DISEASE}

His early publications included papers on respiratory and gastric physiology, paroxysmal atrial rhythm disturbances, complete heart block, the use of quinidine, the heart in thyroid disease, and the effects of exercise on the heart and digestion. $^{3}$ His publications on arrhythmias stressed the importance of understanding aetiology, not just treatment. ${ }^{8}$ His enthusiasm for congenital heart disease, which dominated the latter part of his medical life, began in 1947 when he invited Alfred Blalock from Johns Hopkins Hospital to visit Guy's to perform the exciting first "blue baby operation" in Great Britain. ${ }^{5}$ This led to an intense period of surgical development and close collaboration with Russell Brock and Charles Baker that would make Guy's Hospital famous for its surgery on congenital heart disease and mitral stenosis. Recognising the great importance of establishing a baseline for their surgical results, Campbell stated: "Soon the physicians who are advising operation will have no experience of its natural course without this. It seems that someone who has lived through this period of change should try to collect what he can before it is too late."11 Taking full advantage of his carefully compiled records, his long clinical experience, his background in physiology, and his intuitive understanding of complex longitudinal data, Campbell provided extensive accounts of the natural history of patent ductus arteriosus, atrial septal defect, ventricular septal defect, aortic stenosis, and the results of surgery in cyanotic and acyanotic congenital heart disease. ${ }^{12-18}$ Campbell's zeal for collecting and analysing data led to a series of reports on the natural history of common congenital diseases and their surgical results which are replete with personal observations not found in current literature, including mini case reports that add to the impact of the article, detailed surgical findings, clinical correlations, and helpful physiologic explanations. In order to provide a searching analysis of their surgical approach to congenital heart disease, Brock organised a group of essential participants at Guy's Hospital, including physicians, surgeons, physiologists, anaesthetists, radiologists, pathologists, and a dentist, that met regularly for discussion. Campbell named the group the Peacock Club in honour of Thomas Peacock who authored Malformations of the human heart in $1855 .{ }^{19}$

\section{COLLABORATION WITH RUSSELL BROCK TO DEVELOP MITRAL VALVOTOMY}

In 1946, Campbell talked to Russell Brock about the possibility of mitral valvotomy surgery. Campbell later remarked: "Probably he [Brock], and certainly not I, did not realise how this talk would change our lives." ${ }^{\prime 5}$ This surgery had been performed only once before by Henry Souttar in 1925 at the London Hospital. Though Souttar's patient survived, the surgery was controversial and provoked such fierce peer opposition that Souttar retreated and it was not repeated. ${ }^{20}$ Brock operated on his first patient with mitral stenosis in September 1948, only four months after Bailey in Philadelphia became the first to report a success. ${ }^{20}$ By 1952, the Guy's surgical team could report on the dramatic results of their first 100 cases of mitral valvotomy in which the overall mortality was $13 \%$, falling below $8 \%$ in the last $50 .{ }^{21}$ They commented: "A future that previously seemed bleak for many patients, generally under 40 and often under 30 years of age, has been completely changed. It is doubtful if we, as doctors, have appreciated how much his disability means to the patient. To be unable to hurry or climb stairs, without paying a penalty, to forgo healthy physical pursuits, to have to sleep propped up in order to avoid suffocating at night, and to live in constant fear of a stroke, of haemorrhage from the lungs, of drowning in his own expectoration, or of becoming waterlogged, are just a few of his troubles. What a load is here for anyone to carry, and what a nightmare for the apprehensive. No wonder that patients seize the chance that surgery now offers."

\section{PERSONAL FEATURES AND CONTRIBUTIONS}

An attractive man with a ruddy complexion, wavy gray then silver hair, and a military style moustache, Campbell was above all a gentleman, reserved but still approachable, private without many close friends, who was an excellent, all round clinician held in great affection by his patients for his kindness. In the face of an obvious case of mismanagement by a referring general practitioner, Campbell deflected criticism by remarking to his postgraduate students: "Whatever you may think of this doctor's ability, it is obvious from the referring letter and from the patient's attitude that he is a very kind man." Unlike several of his flamboyant and better dressed contemporaries, Campbell was not a showman but was regarded as unassuming, fair minded, learned, and generous to his junior staff. His talks were a pleasing blend of medical history, clinical wisdom, and an astute demonstration of the practical significance of recent advances. He was valued for his scholarly opinions, organisational and editorial skills, and for his careful statistical work which was advanced for its time and of great importance in the early understanding and treatment of congenital heart disease and arrhythmias. 
In 1956, Campbell summed up his life's work at Guy's Hospital, which had improved the condition of so many, by saying: "It is good for you to argue about what will happen under certain conditions, but do not let these arguments prevent you trying to find out by practical experience what the answer is." 22

\section{ACKNOWLEDGEMENTS}

I am grateful for the assistance of Mrs Marjory Stanley and Drs Douglas Chamberlain, Walter Somerville, MG Thorne, Gaston Bauer, CA Bucknall, Arthur Hollman, JC Houston, Aubrey Leatham, Kenneth Maclean, Robert Knight, and Harold Ellis. The help of the library staff of the Sauls Memorial Library at Piedmont Hospital and Linda Mason is most appreciated.

\section{REFERENCES}

1 Campbell M. Acyanotic congenital heart disease. Guy's Hosp Gaz 1956;70:246-56.

2 Smith KS. Maurice Campbell. Br Heart J 1972;34:1-2.

3 Obituary. Maurice Campbell. BMJ 1973;ii:412.

4 Smith KS. Obituary: Maurice Campbell. Br Heart J 1973;35:1202-4

5 Obituary: Campbell, John Maurice Hardman. Munk's Roll 1966-75;6:86-7.

6 Campbell M. The British Cardiac Society and the cardiac club: 1922-61. Br Heart J 1962;24:673-95.

7 Hollman A. Societies, journals and books. In: Silverman ME, Fleming PR, Hollman A, et al, eds. British cardiology in the twentieth century. London: Springer-Verlag, 2000:66-7
8 Campbell M. The St. Cyres lecture on the aetiology of cardiac arrhythmias. Guy's Hosp Rep 1935;85:471-504.

9 Campbell M. The paroxysmal tachycardias. Lancet 1947;ii:641-83.

10 Campbell M. Birds seen during a crossing of the North Atlantic, 16th-23rd October 1954. Br Birds 1955;40:208-10.

11 Campbell M. Sherlock Holmes and Dr. Watson. Guy's Hosp Gaz 1934-35:524-30.

12 Campbell M. Natural history of persistent ductus arteriosus. Br Heart 1968;30:4-13.

13 Campbell M, Neill C, Suzman S. The prognosis of atrial septal defect. BMJ 1957;i:1375-83.

14 Brotmacher L, Campbell M. The natural history of ventricular septal defect. Br Heart J 1958;20:97-115.

15 Campbell M. The natural history of congenital aortic stenosis. Br Heart $\mathrm{J}$ 1968:30:514-26.

16 Campbell M, Deuchar DC, Brock R. Results of pulmonary valvotomy and infundibular resection in 100 cases of Fallot's tetralogy. BMJ 1954;ii: 111-22.

17 Campbell M. The Blalock-Taussig operation for morbus coeruleus. Guy's Hosp Rep 1948;97:1-47.

18 Brock RC, Campbell M. Valvulotomy for pulmonary valvular stenosis. Br Heart J 1950;12:377-402.

19 Treasure T. Cardiac surgery. In: Silverman ME, Fleming PR, Hollman A, et al, eds. British cardiology in the twentieth century. London: Springer-Verlag, 2000:199

20 Treasure T, Hollman A. The surgery of mitral stenosis 1898-1948: why did it take 50 years to establish mitral valvotomy? Ann R Coll Surg Engl 1995:77:145-51.

21 Baker C, Brock RC, Campbell M. Valvotomy for mitral stenosis. BMJ 1952;i:1043-55.

22 Campbell M. Forty years of cardiology. Guy's Hosp Gaz 1957;71:211-17.

\section{IMAGES IN CARDIOLOGY}

\section{Multiple coronary artery fistulas visualised by three dimensional computed tomography}

A 73 year old woman was admitted to our hospital with symptoms of congestive heart failure. Transthoracic echocardiography revealed an unusual chamber in front of the right ventricle which probably indicated a right coronary fistula. Coronary angiography demonstrated extremely dilated left and right coronary arteries and coronary artery fistulas that became to be tortuous configuration (below left: left coronary angiography, below right: right coronary angiography). Although both arteries seemed to connect to the right atrium, the exact effluent sites were not clearly identified. Six months later, she was readmitted to our hospital because of worsening congestive heart failure and died of unexpected fatal ventricular arrhythmia. At necropsy, both left and right coronary arteries dilated and were tortuously running the surface of the heart. After filling the coronary lumen with contrast material, 3-dimensional CT image was obtained to identify the anatomy of these fistulas. There was the remarkably dilated right coronary artery with the fistula, and the fistula arising from the left circumflex artery was clearly visualised (right, upper panel: a CT image of whole heart; right, lower panel: a CT image of coronary fistula subtracted from heart). Both left and right fistulas terminated at the coronary sinus vein and then drained into the right atrium.

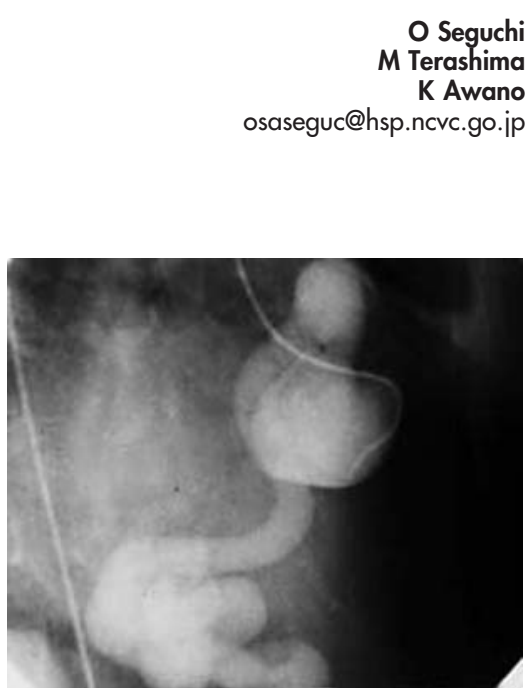

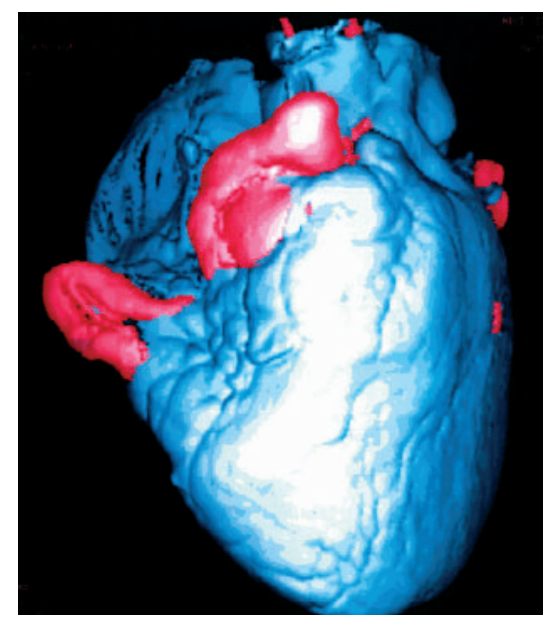

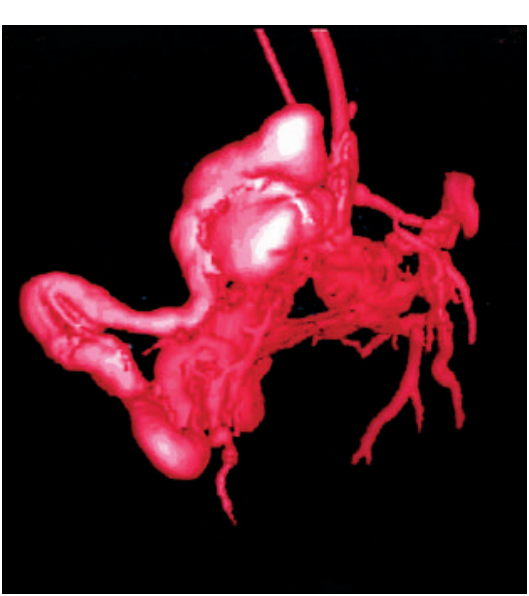

